\title{
Mice as paratenic hosts of Aelurostrongylus abstrusus
}

\author{
Vito Colella ${ }^{1}$, Martin Knaus ${ }^{2}$, Olimpia Lai ${ }^{1}$, Carlo Cantile ${ }^{3}$, Francesca Abramo ${ }^{3}$, Steffen Rehbein ${ }^{2}$ and \\ Domenico Otranto $^{1 *}$
}

\begin{abstract}
Background: Several species of nematodes included in the superfamily Metastrongyloidea are recognized agents of parasitic infections in felines. Aelurostrongylus abstrusus is the most prevalent species affecting the respiratory system of domestic cats. The route of infection in cats is supposed to be through ingestion of gastropod intermediate or paratenic hosts. However, because gastropods are not the preferred preys of cats, rodents were suggested to play an important role as paratenic hosts in the biological cycle of A. abstrusus and in the epidemiology of aelurostrongylosis.
\end{abstract}

Results: Two studies were conducted to document histopathological tissue lesions in mice experimentally infected with A. abstrusus third-stage larvae (L3) (Study 1), and to determine larval counts in their organs (Study 2). Additionally, cats were fed with experimentally infected mice to assess their infectivity. Aelurostrongylus abstrusus L3 were recovered from the liver, spleen, brain, skeletal muscle and gastrointestinal tract tissues by artificial digestion, and heart, spleen and brain tested positive for A. abstrusus at molecular diagnosis. Multifocal encephalitis and meningitis and glial nodules were the most common histopathological lesions found in mice inoculated with $A$. abstrusus. All cats shed first-stage larvae of A. abstrusus after ingestion of mice inoculated with this nematode.

Conclusions: In this study, we provide information on the anatomical localization, histopathological alterations and rate of recovery of $A$. abstrusus $L 3$ in mice, and confirm their infectivity to cats (definitive hosts) after feeding on infected mice (paratenic hosts). Data presented here add knowledge to further understand the biology of $A$. abstrusus in mice and underline the importance of mice as paratenic hosts of this nematode for the infection of cats.

Keywords: Feline, Cats, Paratenic host, Rodents, Mice, Epidemiology, Lungworm

\section{Background}

Infection with several species of nematodes of the superfamily Metastrongyloidea may trigger cardiopulmonary clinical signs in feline hosts [1-3]. While some of them, such as Troglostrongylus brevior [4,5] and Angiostrongylus chabaudi [6] have only recently been found to affect domestic cats, Aelurostrongylus abstrusus has been historically designated as the cat lungworm [7]. These metastrongyloids parasitize both domestic and wild felids, and their life-cycles involve gastropods (snails and slugs) as intermediate hosts $(\mathrm{IHs})$, often coexisting in the same ecological niches $[7,8]$. A recent large-scale survey in Europe demonstrated that $11 \%$ of domestic cats are infected

\footnotetext{
* Correspondence: domenico.otranto@uniba.it

${ }^{1}$ Dipartimento di Medicina Veterinaria, Università degli Studi di Bari, Str. prov. per Casamassima km 3, 70010 Valenzano (Bari), Italy

Full list of author information is available at the end of the article
}

with at least one species of lungworm, mainly A. abstrusus and T. brevior, or co-infected by lungworm species [2].

The clinical and pathological presentation of feline aelurostrongylosis is mainly related to the inflammatory reaction caused by immature stages and to the localization of the adult nematodes in the respiratory system (i.e. bronchioles and alveolar ducts) [9]. Transmission of $A$. abstrusus to its definitive hosts may occur through the ingestion of gastropods, but it is thought to be mainly due to the predation of vertebrates that serve as paratenic hosts (PHs) [7]. In addition, shedding of infective third-stage larvae (L3) into the environment by gastropods [10] and snail-to-snail transmission, referred to as intermediesis [11], have been proposed as alternative routes of transmission for feline lungworms in $\mathrm{IH}$ populations. However, although lacking confirmatory data, there is an alleged emetic effect caused by the 
ingestion of molluscs [4], and gastropods are not the prey of choice in domestic cats' dietary habits [12]. Thus, the attitude of cats towards the predation of potential PHs (i.e. rodents, birds, reptiles and frogs) are likely of importance in the transmission and the maintenance of the life-cycle of the parasite [7, 13-16].

In the early 20th century, mice were erroneously indicated as intermediate hosts of A. abstrusus [17], and further studies attempted to understand the role of mice as PHs $[15,18,19]$. Nevertheless, limited data is available on the anatomical localization of A. abstrusus L3 in mice and their infectivity to cats after ingestion of infected rodents.

This study provides information on the anatomical localization, the histopathology, and the rate of recovery of $A$. abstrusus L3 in experimentally infected mice, and on the infectivity for cats of $A$. abstrusus after ingestion of mice previously inoculated with different $A$. abstrusus larval doses.

\section{Results}

\section{Study 1}

No gross lesions were observed at necropsy of mice infected with $30 \mathrm{~A}$. abstrusus L3 and necropsied 10, 20, 30, 45 and 60 days post-inoculation (dpi) (two mice per time point) and mice which served as uninfected controls.

Examination of mice infected with $30 \mathrm{~A}$. abstrusus L3 allowed for the recovery of single L3 from the liver, spleen and brain by artificial digestion, and heart, spleen and brain tested positive for A. abstrusus DNA (Table 1). Histopathological examination of the brain, spleen, liver, kidneys, lungs and diaphragm, however, revealed microscopical changes of variable extent, onset and duration of occurrence relative to the time point of inoculation, with the brain as the organ which most often showed histopathological changes (Table 2).
The main observations in the brain tissue comprised multifocal encephalitis with perivascular cuffing of small lymphocytes (Fig. 1a, b) and multifocal lymphocytic meningitis (Fig. 1b) which were observed at each time point. In addition, glial nodules, either small or large, composed of histiocytic-like cells, lymphocytes and rare multinucleated giant cells (Fig. 1c, d) were observed from 20 dpi on. In one mouse examined at $20 \mathrm{dpi}$, a third-stage larva was found within the cerebrum tissue (Fig. 2).

Up to $30 \mathrm{dpi}$, multiple foci of extramedullary haematopoiesis with hyalinosis as a rare finding, and extramedullary haematopoiesis and periductal mixed inflammation were the main changes observed in the spleen and liver tissues, respectively (Fig. 3a, b). In addition, a few eosinophils were detected in periductal location and within small parenchymal granulomas in one mouse examined at $20 \mathrm{dpi}$ (Fig. 3c).

Multifocal infiltrates (composed mainly of mononuclear cells) in the cortical and medullary interstitium (Fig. 3d) and mild lesions characterized by multifocal lymphocytic peribronchial and occasionally subpleural infiltrates and pneumonitis (Fig. 4a) were the histological changes recorded up to $30 \mathrm{dpi}$ in the kidneys and lungs of infected mice, respectively. Histological examination of the heart was unremarkable, except for one animal which showed a small subepicardial aggregation of lymphocytes at $20 \mathrm{dpi}$ (Fig. 4b). The serous membrane of the diaphragm was markedly thickened through the presence of a dense mixed infiltrate composed of reactive mesothelial cells, macrophages and lymphocytes with rare granulocytes, whereas lymphocytic aggregates were observed within the muscle (diaphragmitis) from $30 \mathrm{dpi}$ on (Fig. 4c, d).

\section{Study 2}

The number of L3 recovered by artificial digestion from the gastrointestinal tract (GIT) organs, internal organs

Table 1 Study 1. Results of examination of organs of mice inoculated with $\sim 30$ A. abstrusus third-stage larvae each at intervals after inoculation (two mice per time point) by artificial digestion and for detection of A. abstrusus DNA

\begin{tabular}{|c|c|c|c|c|c|c|c|c|c|c|}
\hline \multirow[t]{4}{*}{ Mouse } & \multicolumn{10}{|c|}{ Days post-inoculation of $\sim 30$ A. abstrusus third-stage larvae } \\
\hline & \multicolumn{2}{|l|}{10} & \multicolumn{2}{|l|}{20} & \multicolumn{2}{|l|}{30} & \multicolumn{2}{|l|}{45} & \multicolumn{2}{|l|}{60} \\
\hline & $\overline{\mathrm{AD}}$ & $P C R$ & $\overline{\mathrm{AD}}$ & $P C R$ & $\overline{\mathrm{AD}}$ & PCR & $\overline{\mathrm{AD}}$ & PCR & $\overline{\mathrm{AD}}$ & PCR \\
\hline & 1 & 2 & 1 & 2 & 1 & 2 & 1 & 2 & 1 & 2 \\
\hline Brain & 0 & - & 1 & - & 1 & - & 0 & - & 0 & + \\
\hline Diaphragm & 0 & - & 0 & - & 0 & - & 0 & - & 0 & - \\
\hline Heart & 0 & + & 0 & - & 0 & - & 0 & - & 0 & - \\
\hline Kidneys & 0 & - & 0 & - & 0 & - & 0 & - & 0 & - \\
\hline Liver & 1 & - & 0 & - & 0 & - & 0 & - & 0 & - \\
\hline Lungs & 0 & - & 0 & - & 0 & - & 0 & - & 0 & - \\
\hline Spleen & 1 & + & 0 & - & 0 & - & 0 & - & 1 & - \\
\hline Skeletal muscle & 0 & - & 0 & - & 0 & - & 0 & - & 0 & - \\
\hline
\end{tabular}

Abbreviations: $A D$ artificial digestion: actual number of $A$. abstrusus third-stage larvae recovered from half of an organ's digest, $P C R$ detection of $A$. abstrusus DNA by PCR; +, PCR-positive, -, PCR-negative 
Table 2 Study 1. Frequency of major histopathological changes recorded in the organs of mice inoculated with $\sim 30$ A. abstrusus third-stage larvae each by histological examination of half organs at intervals after inoculation (two mice per time point)

\begin{tabular}{|c|c|c|c|c|c|c|c|c|c|}
\hline \multirow{3}{*}{$\begin{array}{l}\text { Days after } \\
\text { inoculation }\end{array}$} & \multicolumn{9}{|c|}{ Number of mice demonstrating histopathological alterations in the } \\
\hline & \multicolumn{3}{|l|}{ Brain } & \multirow{2}{*}{$\begin{array}{l}\text { Spleen } \\
\text { Multifocal } \\
\text { extramedullar } \\
\text { haematopoiesis }\end{array}$} & \multirow{2}{*}{$\begin{array}{l}\text { Liver } \\
\text { Extramedullar } \\
\text { haematopoiesis }\end{array}$} & \multirow[b]{2}{*}{$\begin{array}{l}\text { Kidneys } \\
\text { Multifocal } \\
\text { mononuclear } \\
\text { cell infiltration } \\
\text { of cortical } \\
\text { and medullary } \\
\text { interstitium }\end{array}$} & \multirow{2}{*}{$\begin{array}{l}\text { Lungs } \\
\text { Multifocal } \\
\text { lymphocytic } \\
\text { peribronchial } \\
\text { inflitration }\end{array}$} & \multicolumn{2}{|l|}{ Diaphragm } \\
\hline & $\begin{array}{l}\text { Multifocal } \\
\text { encephalitis } \\
\text { with perivascular } \\
\text { cuffing of small } \\
\text { lymphocytes }\end{array}$ & $\begin{array}{l}\text { Multifocal } \\
\text { lymphocytic } \\
\text { encephalitis }\end{array}$ & $\begin{array}{l}\text { Glial } \\
\text { nodules }\end{array}$ & & & & & $\begin{array}{l}\text { Thickening } \\
\text { of serous } \\
\text { membrane } \\
\text { through } \\
\text { mixed cell } \\
\text { infiltration }\end{array}$ & $\begin{array}{l}\text { Lymphocytic } \\
\text { diaphragmitis }\end{array}$ \\
\hline 10 & $2 / 2$ & $2 / 2$ & $0 / 2$ & $1 / 2$ & $1 / 2$ & $1 / 2$ & $1 / 2$ & $0 / 2$ & $0 / 2$ \\
\hline 20 & $2 / 2$ & $2 / 2$ & $1 / 2$ & $1 / 2$ & $1 / 2$ & $1 / 2$ & $2 / 2$ & $0 / 2$ & $0 / 2$ \\
\hline 30 & $2 / 2$ & $2 / 2$ & $1 / 2$ & $1 / 2$ & $2 / 2$ & $1 / 2$ & $2 / 2$ & $1 / 2$ & $1 / 2$ \\
\hline 45 & $1 / 2$ & $1 / 2$ & $2 / 2$ & $0 / 2$ & $0 / 2$ & $0 / 2$ & $0 / 2$ & $1 / 2$ & $1 / 2$ \\
\hline 60 & $2 / 2$ & $2 / 2$ & $2 / 2$ & $0 / 2$ & $0 / 2$ & $0 / 2$ & $0 / 2$ & $2 / 2$ & $2 / 2$ \\
\hline
\end{tabular}

(i.e. combined brain, heart, lungs, spleen and liver) and skeletal muscles of mice each inoculated with 50,150 , 300 or $600 \mathrm{~A}$. abstrusus L3 (two mice per dose) and necropsied at $9 \mathrm{dpi}$, and mean total recovery rates of $A$. abstrusus L3 are shown in Table 3. Mean total recovery rates among these groups ranged from $12 \%$ (mice inoculated with $50 \mathrm{~A}$. abstrusus L3 each) to $44 \%$ (mice inoculated with $600 \mathrm{~A}$. abstrusus L3 each). No larvae were isolated from mice of the negative (uninfected) control group. Of the four cats which were fed one mouse each (inoculated with approximately 50,150, 300 or $600 \mathrm{~A}$. abstrusus L3), the two that were fed mice inoculated with 300 and 600 A. abstrusus L3 vomited within one hour of feeding; however, the vomit was consumed soon after by the cats. First-stage $A$. abstrusus larvae were recovered from the faeces of all four cats at 43,44 and 48 dpi (range: 4-910, 2-1050 and 1-5250 larvae per $10 \mathrm{~g}$ of faeces, respectively). No larvae were recovered from the faeces of the cat fed with the uninfected mouse.

\section{Morphological and molecular identification of larvae}

Morphology of A. abstrusus L1 and L3 collected from the faeces of donor cats or from snails and mice following artificial digestion, respectively, were consistent with

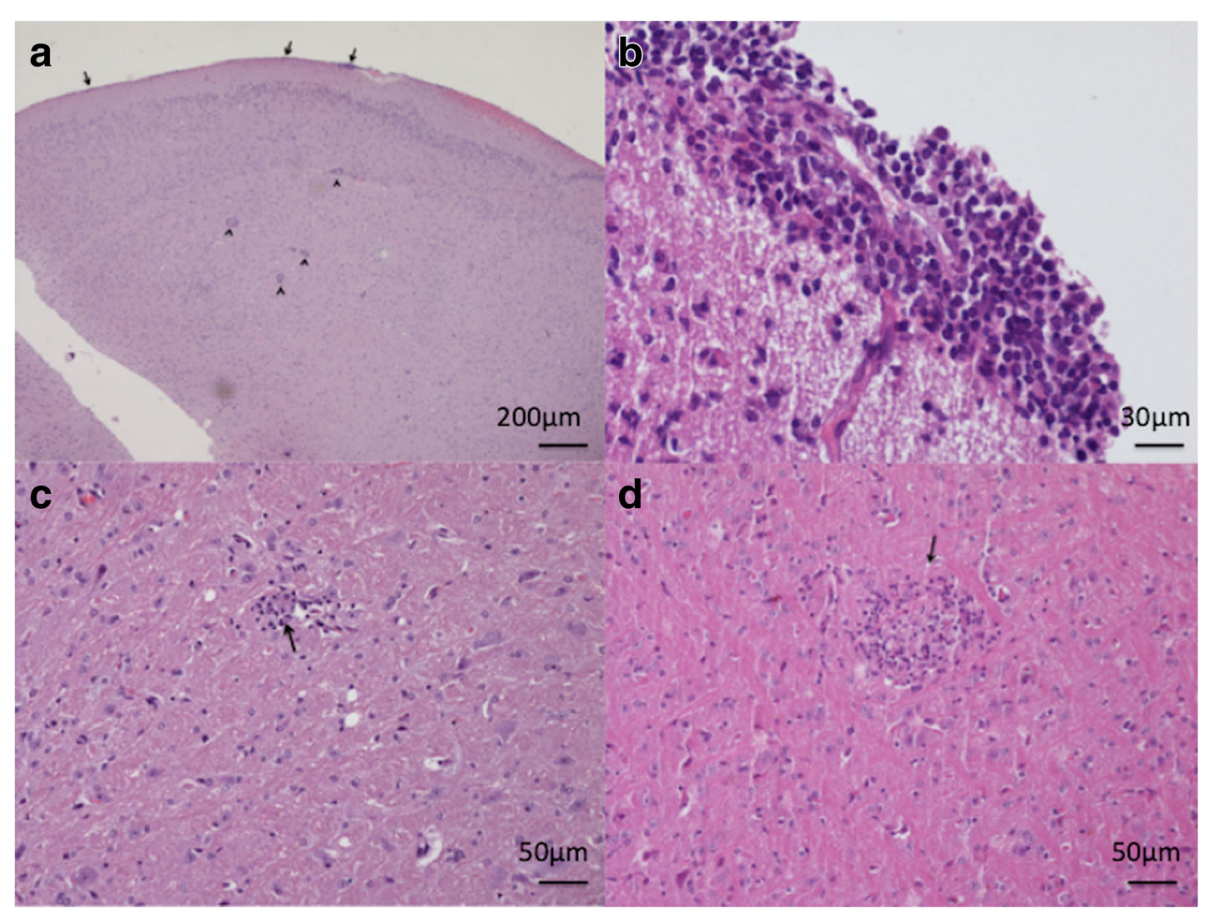

Fig. 1 Study 1. Brain. a Meningitis (arrows) and encephalitis with lymphocytic perivascular cuffing (arrowhead). b Lymphocytic meningitis. c Small glial nodule (arrow). $\mathbf{d}$ Large glial nodule (arrow). Scale-bars: $\mathbf{a}, 200 \mu \mathrm{m} ; \mathbf{b}, 30 \mu \mathrm{m}, \mathbf{c}, \mathbf{d}, 50 \mu \mathrm{m}$ 


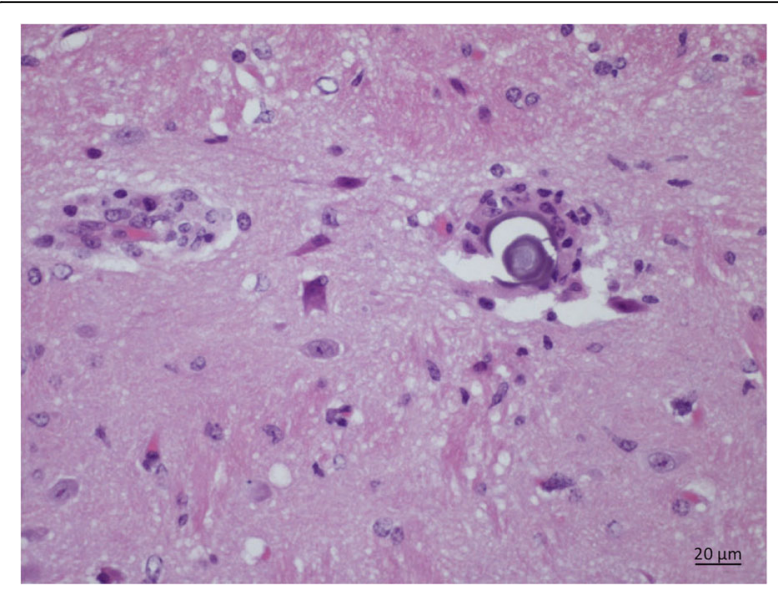

Fig. 2 Study 1. Localization of a third-stage larva of Aelurostrongylus abstrusus in the brain of a mouse analysed at 20 dpi. Scale-bar: $20 \mu \mathrm{m}$

previous descriptions $[14,20]$. All $18 S$ rDNA sequences obtained from the L1 and the L3 displayed 100\% identity to the nucleotide sequence of $A$. abstrusus deposited in GenBank (accession no. AJ920366).

\section{Discussion}

This study provides information on the localization, histopathological alterations and rate of recovery of $A$. abstrusus L3 in experimentally infected mice and confirms the infectivity of $A$. abstrusus L3-infected mice to cats. Aelurostongylus abstrusus L3 were recovered from several organs of mice including the brain, GIT and skeletal muscles, where the majority of larvae were recovered by tissue digestion. Similarly, in previous studies, L3 were mainly found in the organs such as the liver and the omentum of experimentally and naturally infected mice $[15,18]$. Yet, a study of localization of larvae at different time points and using various diagnostic techniques (i.e. molecular, histopathology and digestion procedures) was not previously performed. Lesions of various extent were detected by histopathology. Tissue alterations, which featured in the form of infiltrates of lymphocytes, eosinophils and macrophages, granulomas and by glial nodules in the brain, were likely a consequence of $A$. abstrusus larval migration. In the brain, the evaluation of serial longitudinal sections allowed for the description of focal lesions and the detection of one larva at 20 dpi despite the overall low level of challenge with 30 A. abstrusus L3. This finding is in accordance with the results of PCR and artificial digestion of tissues which allowed for the detection of $A$. abstrusus DNA and the recovery of $A$. abstrusus $\mathrm{L} 3$ from the brain and other organs of mice. The detection of A. abstrusus L3 in the brain of mice may be suggestive of neurotropism as shown for other species within the family Angiostrongylidae in other than definitive hosts $[1,21-23]$. Whether this anatomical localization

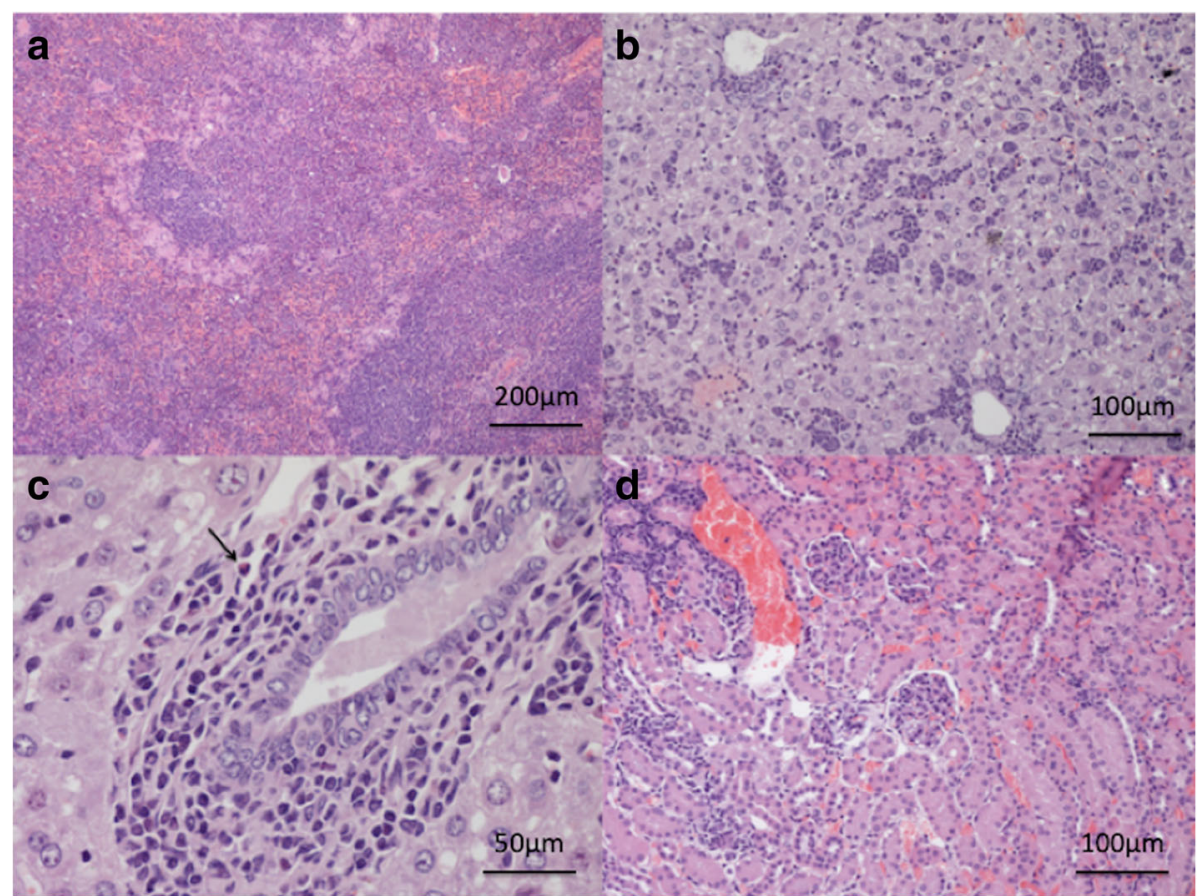

Fig. 3 Study 1. a Spleen. Hyperplasia with hyalinosis, extramedullary haematopoiesis at 30 dpi. b Liver. Severe extamedullary haematopoiesis at 30 dpi. c Liver. Cholangitis with very few eosinophils (arrow) at 20 dpi. d Kidneys. Interstitial nephritis and glomerulonephritis focal and segmental mesangioproliferative glomerulonephritis at 20 dpi. Scale-bars: a, $200 \mu \mathrm{m} ; \mathbf{b}, \mathbf{d}, 100 \mu \mathrm{m}, \mathbf{c}, 50 \mu \mathrm{m}$ 


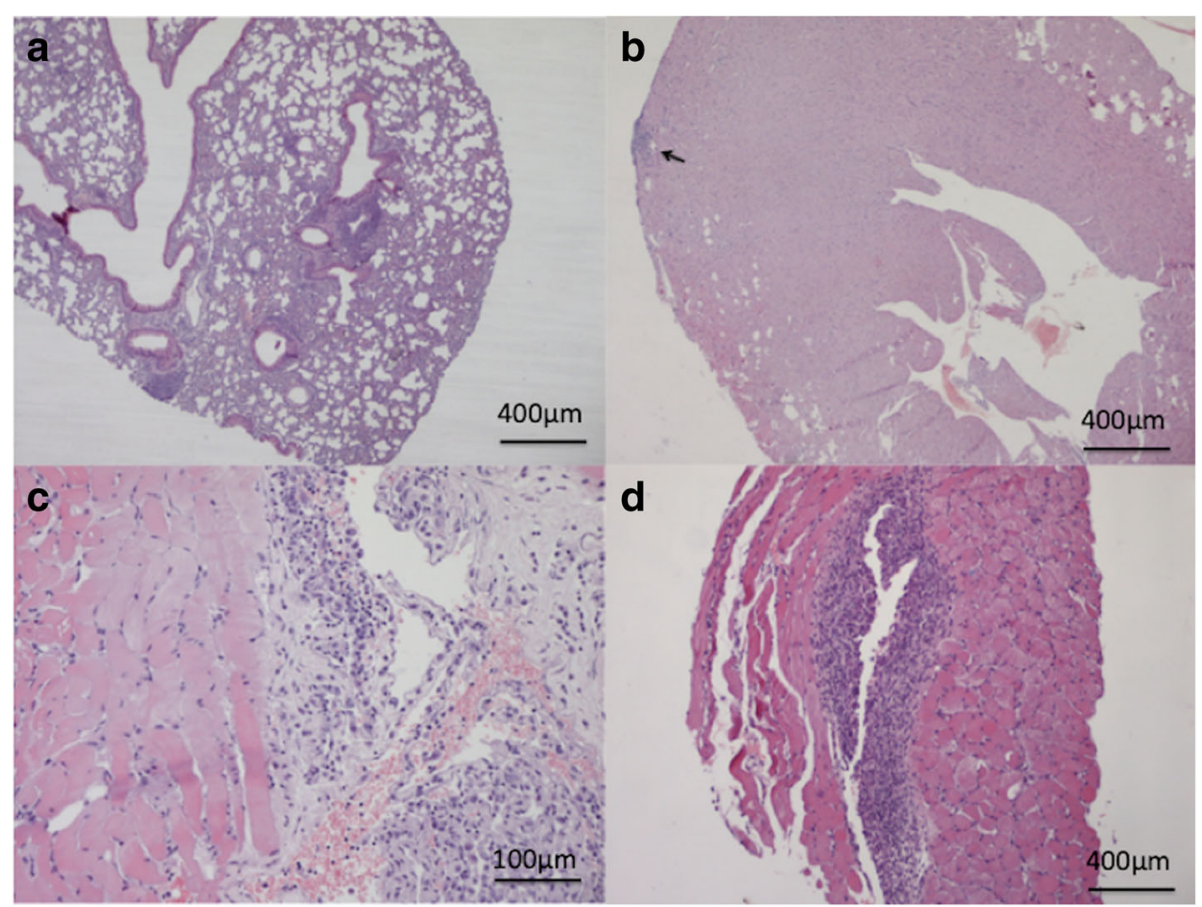

Fig. 4 Study 1. a Lungs. Peribronchial lymphoid infiltrates at 20 dpi. b Heart. Focal very mild subepicardial myocarditis (arrow) at 20 dpi. c Diaphragm. Severe granulomatous serositis at 45 dpi. d Diaphragm. Granulomatous myositis at 45 dpi. Scale-bars: a, b, d, $400 \mu m ; \mathbf{c}, 100 \mu m$

influences the behaviour of mice is unknown and was not evaluated in the present studies. However, none of the infected mice in these studies showed signs of behavioural abnormality.

Cats experimentally infected with $A$. abstrusus L3 either within gastropods or through another source invariably vomited [18]. The mechanism causing vomiting is not known, but it is likely that a large number of infective L3 invading the gastric mucosa may cause an irritation, eventually resulting in this outcome [18]. Similarly, the two cats fed with mice that were inoculated with the highest numbers of $A$. abstrusus L3 (i.e. 300 and 600 L3) in Study 2 vomited after consumption of the mice carcasses. Nonetheless, as also observed in these animals, cats may easily feed on vomited material, therefore favouring the $A$. abstrusus transmission.

Mice live in close vicinity to cats, being also present in human dwellings, and represent a much more attractive prey to cats compared to gastropods [12]. Cameron [17, 24] in 1926 claimed the successful development of $A$. abstrusus L1 into L3 in mice and recovered adult nematodes in cats after experimental infection with these mice. However, the length of the L3 $(c .700 \mu \mathrm{m})$ recovered from mouse tissues [17] and the recovery of adult nematodes from the cardiopulmonary blood vessels of experimentally infected cats $[14,18,25]$ remained puzzling. Therefore, it was argued that an as-yet-unknown species of lungworm infected the cats [18]. Although no species assignation will be possible for Cameron's findings,

Table 3 Study 2. Number of A. abstrusus third-stage larvae (L3) recovered from organs of mice 9 days after inoculation with various numbers of $A$. abstrusus $L 3$ and percentage rate of recovery

\begin{tabular}{|c|c|c|c|c|c|}
\hline \multirow{2}{*}{$\begin{array}{l}\text { No. of } L 3 \text { inoculated } \\
\text { per mouse }\end{array}$} & \multicolumn{4}{|c|}{ No. of L3 recovered from two mice (mean \pm standard deviation) } & \multirow{2}{*}{$\begin{array}{l}\text { Mean total } \% \\
\text { recovery rate }\end{array}$} \\
\hline & GIT organs & Internal organs ${ }^{a}$ & Skeletal muscles & Total $^{\mathrm{b}}$ & \\
\hline$\sim 50$ & $2 \pm 1.4$ & $2 \pm 1.4$ & $2 \pm 2.8$ & $6 \pm 2.8$ & 12 \\
\hline$\sim 150$ & $4 \pm 5.7$ & $18 \pm 7.1$ & $14 \pm 4.2$ & $36 \pm 2.8$ & 24 \\
\hline$\sim 300$ & $39 \pm 12.7$ & $79 \pm 9.9$ & $13.5 \pm 9.2$ & $131.5 \pm 6.4$ & 44 \\
\hline$\sim 600$ & $23 \pm 17.0$ & $70 \pm 49.5$ & $10 \pm 8.5$ & $103 \pm 41.0$ & 17 \\
\hline
\end{tabular}

${ }^{a}$ Combined brain, lungs, heart, kidneys, liver, spleen, and diaphragm

${ }^{\mathrm{b}}$ Combined GIT organs, internal organs and skeletal muscles

${ }^{\mathrm{C}}$ Mean total \% recovery rate $=100 \times$ total mean number of $A$. abstrusus $\mathrm{L} 3$ recovered/number of $A$. abstrusus L3 inoculated

Abbreviation: GIT gastrointestinal tract 
Angiostrongylus chabaudi is the only metastrongyloid residing in the vessels of the cardiopulmonary system of felids with L3 measuring approximately $700 \mu \mathrm{m}$ in length [8]. Since cardiopulmonary nematodes may infect both domestic and wild cats and display a complementary transmission pattern in their life-cycles [8], studies on the biology of lungworm species should be encouraged to better define the epidemiology of metastrongyloids infecting felids [26].

\section{Conclusions}

Although the role of mice in the epidemiology of feline aelurostrongylosis is well recognized, in only one study was a single wild-caught Apodemus mouse found to harbour A. abstrusus L3 [15]. Data presented here add knowledge to further understand the biology of $A$. abstrusus in mice and emphasize the risk for the infection of cats living in A. abstrusus endemic areas. Further studies should be performed to assess the risk factors related to the presence of mice in the epidemiology of feline aelurostrongylosis.

\section{Methods}

\section{Study design}

Two studies were designed to document histopathological tissue lesions in mice experimentally infected with $A$. abstrusus L3 (Study 1), and to determine $A$. abstrusus L3 counts in the organs of infected mice and the infectivity in cats after ingestion of A. abstrusus- infected mice (Study 2).

\section{Infection of snails and recovery of $A$. abstrusus $\mathrm{L} 3$}

Field isolates of $A$. abstrusus from naturally infected cats from Italy (Study 1 ) or Hungary (Study 2 ) were used to infect snails (Cornu aspersum). Both isolates had been passed through snails and cats (donor cats) for at least 3 years in the laboratory before being used in these studies. Two days unfed snails were individually placed in infection chambers exposed to A. abstrusus L1 as previously described [27]. Twenty-one days from the exposure to larvae, snails were humanely euthanized by menthol steam exposure in a plastic box and the snail tissues were subjected to an artificial digestion protocol to recover $A$. abstrusus L3s [27]. The sediment was washed twice and the larvae were collected in a clean solution with the aid of a micropipette under a light microscope. The product was considered the bulk L3 suspension.

\section{Experimental infection of mice}

In total 30 male mice (Mus musculus) weighing 12.4-16.7 g were used (Study 1, 15 mice; Study 2, 15 mice). The mice were acclimatized to the study environment for at least seven days prior to inoculation. Individual doses of $A$. abstrusus L3 (i.e. Study 1, approximately 30 L3; Study 2, approximately 50, 150, 300 and 600 L3) were prepared and suspended in saline solution. For inoculation, the individual inoculum was concentrated to $<0.05 \mathrm{ml}$, withdrawn in a 1 $\mathrm{ml}$ disposable syringe and administered orally by means of a buttoned cannula. Care was taken to ensure complete swallowing of the inoculum.

\section{Study 1}

Ten mice were inoculated with approximately $30 \mathrm{~A}$. abstrusus L3 each. At 10, 20, 30, 45 and 60 dpi two mice (designated as Mouse 1' and Mouse 2'), were randomly selected from the group, humanely euthanized and necropsied. The remaining five mice served as uninfected controls, and one of these was processed in parallel at each day of necropsy.

At each time point the brain, lungs, heart, kidneys, liver, spleen and diaphragm of the Mouse 1' were split into two equal portions of which one was subjected to artificial peptic digestion as described in [27] and the other portion was processed for the histopathological examination. In the Mouse 2', the abovementioned organs were similarly split into two portions and processed either for histopathology or molecular analysis.

For histopathological examination, organs were fixed in $10 \%$ buffered formalin solution (pH 7.4), and embedded in paraffin. Sections of $5 \mu \mathrm{m}$ were stained with haematoxylin and eosin. To ensure an adequate histological evaluation, samples were obtained according to the guideline for sampling and trimming in mice $[28,29]$. In particular, the following anatomical sections of organs were evaluated: brain (forebrain at level of the optic chiasm, at the base of the posterior hypothalamus and at the level of the caudal thalamus, mid cerebellum and medulla oblongata), spleen (transverse section), liver (left lateral and right medial lobe), kidneys (longitudinal section), lung (left lobe), heart (longitudinal section) and diaphragm (longitudinal section). All tissue sections were carefully read for pathological changes. Organs of the control mice were only subjected to examination for gross lesions and to digestion procedures.

\section{Study 2}

Fifteen mice were formed randomly in five groups of three, and three mice each were inoculated with approximately 50, 150, 300 or 600 A. abstrusus L3 as described above or remained uninfected as negative control. At 9 dpi all mice were humanely euthanized.

Two mice of each group were necropsied and the GIT organs (stomach and intestine including mesentery and omentum), internal organs (combined brain, lungs, heart, kidneys, liver, spleen and diaphragm) and skeletal muscles were collected and subjected to artificial digestion. Following digestion, the number of $A$. abstrusus L3 was counted, and the mean total \% recovery rate 
[(number of L3 collected from the organs' digest/number of inoculated L3) $\times$ 100] was calculated.

The carcass of one mouse of each group was fed to one European Short Hair cat (male castrated, purpose bred, approximately 11 to 14 months of age) that was confirmed negative for $A$. abstrusus based on faecal examination prior to inoculation. For inoculation of the cats, carcasses of mice were cut in pieces and offered to the cats in place of their regular food. Care was taken that the carcass was completely consumed. Individual $10 \mathrm{~g}$ faecal samples were collected from all cats at 43, 44 and $48 \mathrm{dpi}$ and subjected to the Baermann-Wetzel migration technique for $A$. abstrusus L1 recovery and count.

\section{Morphological and molecular identification of nematode larvae}

Aelurostrongylus abstrusus L1 and L3 were identified based on their morphology according to previous descriptions [14, 20]. For molecular analysis, $10 \mathrm{~L} 1 \mathrm{col}-$ lected from the faeces of the donor cats and $10 \mathrm{~L} 3$ collected after artificial digestion of snail tissues were used. Genomic DNA was extracted using a commercial kit (DNeasy Blood \& Tissue Kit; Qiagen, Hilden, Germany) from the larvae and selected organs of the experimentally infected mice, in accordance with the manufacturer's instructions, and a partial fragment of the nuclear $18 S$ rDNA ( 1700 bp) ribosomal gene was amplified using the primers NC18SF1 (5'-AAA GAT TAA GCC ATG CA-3') and NC5BR (5'-GCA GGT TCA CCT ACA GAT-3'), as previously described [20]. The amplicons were purified and sequenced in both directions using the same primers as for PCR, employing the Taq Dye Deoxy Terminator Cycle Sequencing Kit v.2 (Applied Biosystems, Foster City, California, USA) in an automated sequencer (ABI-PRISM 377; Applied Biosystems, Foster City, California, USA). Sequences were edited and aligned using the Geneious R9.1 software package (http://www.geneious.com) and compared with those available in the GenBank database, using the Basic Local Alignment Search Tool (BLAST, http://blast .ncbi.nlm.nih.gov/Blast.cgi).

\section{Acknowledgements}

The authors are grateful to Francesca Fazio and Dr Giada Annoscia for their technical assistance during laboratory work.

\section{Funding}

This research received no specific grant from any funding agency, commercial or not-for-profit sectors.

\section{Availability of data and materials}

The datasets used and/or analysed during the present study are available from the corresponding author upon reasonable request.

\section{Authors' contributions}

VC, DO and MK conceived the study, performed laboratory work and compiled the data. OL, CC and FA performed the histopathological examination of mice tissues. VC provided the first draft of the manuscript and SR critically revised it All authors read and approved the final manuscript

\section{Ethics approval}

All animals were handled with due regard to their welfare and in compliance with the applicable Institutional Animal Care and Use Committee approvals, and with the relevant local animal welfare regulations (Ref. 55.2-1-54-2533.0-78-14)

Consent for publication

Not applicable.

\section{Competing interests}

The authors declare that they have no competing interests.

\section{Publisher's Note}

Springer Nature remains neutral with regard to jurisdictional claims in published maps and institutional affiliations.

\section{Author details}

${ }^{1}$ Dipartimento di Medicina Veterinaria, Università degli Studi di Bari, Str. prov. per Casamassima km 3, 70010 Valenzano (Bari), Italy. ${ }^{2}$ Boehringer Ingelheim Vetmedica GmbH, Kathrinenhof Research Center, Walchenseestr. 8-12, 83101 Rohrdorf, Germany. ${ }^{3}$ Department of Veterinary Sciences, University of Pisa, Viale delle Piagge 2, 56124 Pisa, Italy.

Received: 26 October 2018 Accepted: 7 January 2019

Published online: 22 January 2019

\section{References}

1. Spratt DM. Species of Angiostrongylus (Nematoda: Metastrongyloidea) in wildlife: a review. Int J Parasitol Parasites Wildl. 2015;4:178-89.

2. Giannelli A, Capelli G, Joachim A, Hinney B, Losson B, Kirkova Z, et al. Lungworms and gastrointestinal parasites of domestic cats: a European perspective. Int J Parasitol. 2017;47:517-28.

3. Traversa D, Di Cesare A, Conboy G. Canine and feline cardiopulmonary parasitic nematodes in Europe: emerging and underestimated. Parasit Vectors. 2010;3:62

4. Brianti E, Giannetto S, Dantas-Torres F, Otranto D. Lungworms of the genus Troglostrongylus (Strongylida: Crenosomatidae): neglected parasites for domestic cats. Vet Parasitol. 2014;202:104-12.

5. Jefferies R, Vrhovec MG, Wallner N, Catalan DR. Aelurostrongylus abstrusus and Troglostrongylus sp. (Nematoda: Metastrongyloidea) infections in cats inhabiting Ibiza, Spain. Vet Parasitol. 2010;173:344-8.

6. Varcasia A, Tamponi C, Brianti E, Cabras PA, Boi R, Pipia AP, et al. Angiostrongylus chabaudi Biocca, 1957: a new parasite for domestic cats? Parasit Vectors. 2014;7:588.

7. Anderson RC. Nematode Parasites of Vertebrates: Their Development and Transmission. Wallingford: CABl; 2000

8. Colella V, Cavalera MA, Deak G, Tarallo VD, Gherman CM, Mihalca AD, et al. Larval development of Angiostrongylus chabaudi, the causative agent of feline angiostrongylosis, in the snail Cornu aspersum. Parasitology. 2017;144: 1922-30

9. Elsheikha HM, Schnyder M, Traversa D, Di Cesare A, Wright I, Lacher DW. Updates on feline aelurostrongylosis and research priorities for the next decade. Parasit Vectors. 2016;9:389.

10. Giannelli A, Colella V, Abramo F, do Nascimento Ramos RA, Falsone L,

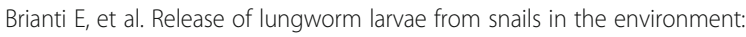
potential for alternative transmission pathways. PLoS Negl Trop Dis. 2015;9: e0003722

11. Colella V, Giannelli A, Brianti E, Ramos RAN, Cantacessi C, Dantas-Torres F, et al. Feline lungworms unlock a novel mode of parasite transmission. Sci Rep. 2015;5:13105

12. Woods M, Mcdonald R, Harris S. Predation of wildlife by domestic cats Felis catus in Great Britain. Mamm Rev. 2013;33:177-84.

13. Hobmaier M, Hobmaier A. Mammalian phase of the lung-worm Aelurostrongylus abstrusus in the cat. J Am Vet Med Assoc. 1935;87:191-8.

14. Gerichter CB. Studies on the nematodes parasitic in the lungs of felidae in Palestine. Parasitology. 1949;39:251-62. 
15. Jezewski W, Buńkowska-Gawlik K, Hildebrand J, Perec-Matysiak A, Laskowski Z. Intermediate and paratenic hosts in the life cycle of Aelurostrongylus abstrusus in natural environment. Vet Parasitol. 2013;198:401-5.

16. Falsone L, Colella V, Napoli E, Brianti E, Otranto D. The cockroach Periplaneto americana as a potential paratenic host of the lungworm Aelurostrongylus abstrusus. Exp Parasitol. 2017;182:54-7.

17. Cameron TWM. Observations on the life history of Alurostrongylus abstrusus (Railliet), the lungworm of the cat. J Helminthol. 1927;5:55.

18. Mackerras J. Observations on the life history of the cat lungworm Aelurostrongylus abstrusus (Railliet, 1898) (Nematoda: Metastrongylidae). Aust J Zool. 1957:5:188-95.

19. Hamilton JM, Mccaw AW. The role of the mouse in the life cycle of Aelurostrongylus abstrusus. J Helminthol. 1967:41:309-12.

20. Giannelli A, Ramos RAN, Annoscia G, Di Cesare A, Colella V, Brianti E, et al. Development of the feline lungworms Aelurostrongylus abstrusus and Troglostrongylus brevior in Helix aspersa snails. Parasitology. 2014;141:563-9.

21. Colella V, Lia RP, Premont J, Gilmore P, Cervone M, Latrofa MS, et al. Angiostrongylus vasorum in the eye: new case reports and a review of the literature. Parasit Vectors. 2016;9:161.

22. Wang Q-P, Lai D-H, Zhu X-Q, Chen X-G, Lun Z-R. Human angiostrongyliasis. Lancet Infect Dis. 2008;8:621-30.

23. Ma G, Dennis M, Rose K, Spratt D, Spielman D. Tawny frogmouths and brushtail possums as sentinels for Angiostrongylus cantonensis, the rat lungworm. Vet Parasitol. 2013;192:158-65.

24. Cameron BTWM. On the life history of the lungworm, Synthetocaulus abstrusus, hitherto confused with that of Ollulanus tricuspis in cats. J Helminthol. 1926;4:53-60.

25. Cameron TWM. On the habitat of Aelurostrongylus abstrusus, the lung worm of the cat. J Helminthol. 1928;6:165-6.

26. Otranto D, Brianti E, Dantas-Torres F. Troglostrongylus brevior and a nonexistent "dilemma". Trends Parasitol. 2013;29:517-8.

27. Colella V, Mutafchiev Y, Cavalera MA, Giannelli A, Lia RP, Dantas-Torres F, et al. Development of Crenosoma vulpis in the common garden snail Cornu aspersum: implications for epidemiological studies. Parasit Vectors. 2016;9:208.

28. Ruehl-Fehlert C, Kittel B, Morawietz G, Deslex P, Keenan C, Mahrt CR, et al. Revised guides for organ sampling and trimming in rats and mice - Part 1: a joint publication of the RITA and NACAD groups. Exp Toxicol Pathol. 2004; 55:91-106.

29. Kittel B, Ruehl-Fehlert C, Morawietz G, Klapwijk J, Elwell MR, Lenz B, et al. Revised guides for organ sampling and trimming in rats and mice - Part 2: a joint publication of the RITA and NACAD groups. Exp Toxicol Pathol. 2004; 55:413-31.

Ready to submit your research? Choose BMC and benefit from:

- fast, convenient online submission

- thorough peer review by experienced researchers in your field

- rapid publication on acceptance

- support for research data, including large and complex data types

- gold Open Access which fosters wider collaboration and increased citations

- maximum visibility for your research: over $100 \mathrm{M}$ website views per year

At $\mathrm{BMC}$, research is always in progress.

Learn more biomedcentral.com/submissions 